\title{
The Implemented of Somatic, Auditory, Visualization, Intellectually, Repetition (SAVIR) Strategy toward Improved of Subject Learning Based on Multicultural Social Studies Learning
}

\author{
Ine Kusuma Aryani ${ }^{1}$ and Subuh Anggoro ${ }^{2}$ \\ \{inepascapendas@gmail.com\} \\ Magister Pendidikan Dasar, Universitas Muhammadiyah Purwokerto
}

\begin{abstract}
Associated with this Theme "Empowering Human Development Through Science and Education," I make a title of my research about "The Implemented of SAVIR Strategy Toward Improved of Subject Learning based on Multicultural Social Studies Learning In Basic Education Postgraduate UMP". Generally How common the implemented strategy SAVIR is The Effective to improve understanding of concepts and think students creatively in Learning IPS-based Multicultural on PPS-UMP. This study aims to: 1) Describe strategic planning SAVIR on Multicultural- Based Social Studies learning for PPS UMP Students; 2) knowing the increase in the concept of MulticulturalBased Social Studies Learning in PPS students through the application of SAVIR strategy,3) knowing the increase in the creative thinking skills of PPS students through the application of the problem -based SAVIR strategy. Subject Research is Basic Education Post Graduate (PPS) UMP, whose study about Social Studies/IPS Learning based Multicultural matter, thats material can be defined as a form of awareness about the diversity of cultural, rights fundamental human as well as the reduction or elimination of various types of bias or prejudice to build a life community that fair and forward, education multicultural also be interpreted as as strategy to develop awareness on the pride of a person against his nation (The pride in one's home nation). The results of SAVIR strategy is learning that embraces the flow of science cognitive modern which is states that the most good learning is involve emotion, the whole body, all the senses, and all the depth and breadth of personal, respecting the style of other learning individuals by way of realizing that people learn in ways that differ In this learning, the participants are required to search for and find the solution of a problem with doing. The fifth components of SAVIR integrated manner such the participant students and teachers can together turn the atmosphere of the class - $85 \%$ understand. Learning containers of atmosphere that is varied so as not boring.The procedure of research is to adapt the model of development ADDIE which consists of five phases that include, results and concluse thats: with interview the analysis $80 \%$, design $80 \%$, development $86 \%$, implementation $90 \%$ and evaluation $90 \%$.
\end{abstract}

Keyword: SAVIR Strategy, Problem Solving, IPS Learning of Multicultural.

\section{Introduction}

NKRI, the Unitary State of the Republic of Indonesia is one of the multicultural countries, has a diverse society, ranging from culture, language, religion, ethnicity and so on. 
Recently, many problems have arisen in people's lives, such as religious problems triggered by religious differences to the same religion, problems with government policies, problems with political parties, and ethnic differences. The reduced distribution of welfare and the government's attention to its people has resulted in regions wishing to escape from this country, especially in border areas. Another problem in the field of education is that there are many problems with juvenile delinquency, murder, sexual harassment or rape where the perpetrators are still underage. The various problems above constitute a challenge to improve education in this country, because they have an influence on social, economic, religious, and cultural life, so that Social Science education (IPS) has a very important role in relation to multiculturalism in Indonesia.

Various problems such as in Aceh, Sambas, Ambon and other areas where problems between groups occur which have an impact on the sacrifice of life and property. The decreasing national spirit in the current era, especially the younger generation who is influenced by the development of information and technology continues to increase and is accompanied by the entry of foreign culture which also influences mental thinking, attitudes, behavior, and even clothing that does not reflect society or religion. in the State of Indonesia. Problems like this have a major impact on the advancement of the human resources of the Indonesian people and are interconnected between aspects of the social education sector that do not reflect both society and religion in the State of Indonesia and are interconnected between aspects of the field in relation to the implementation of development, as well as the open integration of one nation. width will be a threat (Sudrajat, 2014:17).

One example of a very small problem but a big problem and the principle that occurs, today many people are always more active in blaming others, especially on religious issues. Religion, which should serve as a guide in carrying out daily life side by side between humans, is actually one of the causes of problems. Religious differences always cause problems, but those with fellow religions participate in causing differences starting from different perspectives, lack of understanding, and eventually forming different groups. In addition, society is more competing with each other or competing which makes a person individualistic. So from the various problems that exist, education is expected as a strategic effort in addressing differences, especially religion, culture, ethnicity, race and can overcome problems that arise in people's lives. Education is at the same time one of the efforts to fulfill better quality human resources as capital in the development of the nation and the State, which currently emphasizes the aspect of character education. When talking about social science or social studies education, students' complaints are that it is difficult to understand because of the large amount of material and they have to read a lot, multicultural-based social studies learning which is unique to understand, with the help of the SAVIR (Somatic, Auditory, Visualization, Intellectually, Repetition) strategy it will be fun and not boring, bringing students to more comfortable studying Social Science.

The research objectives were, 1) To determine the description of Savir strategy planning in Multicultural-Based Social Studies learning for Post-Pendas PPS UMP Students; 2) To determine the increase in the concept of Multicultural Based Social Studies Learning in PostPendas students through the application of problem-based SAVIR strategies; 3) To determine the improvement of post-Pendas students' creative thinking skills through the application of problem-based SAVIR strategies. 


\section{Literature}

\subsection{Understanding the Descriptions and Concepts of Multicultural-Based Social Studies Learning Materials}

Social studies education is learning that shapes students to become citizens in this life who feel peaceful, can have the competence to adapt, synergize and communicate well and can think positively towards others (Saidiharjo, 2004:43). At the elementary level, the integration of social studies which includes history, economics, geography and sociology is described in various topics of a subject. His study of the problem is the main thing in social studies learning. Social studies learning is a whole or a combination of several of these subjects, so this learning requires a variety of models. So Social Science is a subject that combines and integrates various basic concepts of the disciplines of history, geography, economics, sociology for education and can be useful for students in dealing with problems that arise in their lives. Some of the nature of the objectives in the Social Studies subject: Fostering students' knowledge of human experiences in social life in the past, present and future:

1. Students can improve their skills as information progresses.

2. Students can increase the value of attitude (value) in social life upholding democracy.

3. Students are given the opportunity to be able to play a role in the environment of social life (Chapin, in Ichas, et al, 2006)

Social studies learning develops students to make citizens have extensive knowledge, have values, can have a good attitude and can play a role in people's lives by upholding the democratic system that is studied from the aspects of social, economic, historical, geographic and humanities which are interconnected and complementary, this refers to the source of the National Council For The Social Studies (Chapin, in Ichas, et al, 2006). Social studies learning functions include:

1. Provide basic knowledge, both to continue to higher education and to apply it in everyday life.

2. Developing skills in developing social studies concepts

3. Instill a scientific attitude and train students in using scientific methods to solve the problems at hand.

4. Make students aware of the power of nature and all its beauty so that students are motivated to love and glorify their creator

5. Fostering students' creative and innovative power

6. Helping students understand new ideas or information in the field of Science and Technology

7. Cultivate themselves and develop students' interest in social studies (Ishack in Winataputra, 2007).

Mastery of various social science disciplines, social studies education can provide benefits in democratic social life, can instill values in Indonesian citizens with the provision of social sciences, and can instill a scientific attitude to be able to solve the surrounding problems faced. Likewise at school level education, IPS is expected to provide insights to encourage the desire to improve education to a higher level. The integration of social studies learning from various social science disciplines can be done based on certain topics that are still re lated to other disciplines of social studies disciplines. One example is the agricultural activities of the community, this agricultural activity can be developed in terms of the geographical aspect of a particular area, how the distribution of agriculture is, then the majority of the people who farm are how the situation is economically. 
Multicultural education, education mostly directs to learn how to think rather than what is thought, teaches students how to understand knowledge, one of which can be done by increasing discussion activity in order to find different interpretations of understanding (Banks, 1993). In addition, multicultural education is an idea, a movement in the importance of manila diversity of cultures, lifestyles, different social conditions, individual differences, equal opportunities for individuals, groups or countries to obtain education. (Banks, 1993).

Multicultural education is said to be a strategy to take advantage of various cultures with different backgrounds from students, which is unique or characterizes students' cash to form multicultural attitudes. In addition, as a school institution, it can provide a shared understanding of different cultural concepts towards the establishment of a balanced and democratic life that can run properly (Liliweri, 2015). Multicultural education is a new symptom that hopes for equal rights, including the right to get the same education for every human being, this of course runs with a democratic process of human rights whose aim is not to differentiate between people even with different backgrounds. Multicultural education also appreciates many cultures as an objective state in society, its implementation explores various differences, creates a tolerant field of education (Choirul Machfud, 2005).

\subsection{SAVIR Learning Strategy}

Everyone has a different style of thinking and learning style. Some of us can learn best just watching other people do it. They prefer to write down what the facilitator has to say and not be distracted by midwifery. Such learning patterns are called visual learning styles. On the other hand, there are also many students who rely on their listening ability to remember and not a few students have the most effective way of learning by being directly involved in activities.

According to Silberman (2006: 17) Few students have one type of learning. Based on the research results of every 30 students, 22 of them can learn very effectively as long as the teacher presents learning activities in the form of a combination of visual-auditory-kinesthetic. However, the other 8 students only liked one form of learning so they had difficulty understanding the lesson if the delivery method was not suitable for their learning style. In order to meet this need, learning must be multisensory and full of variety

DePorter (2005: 105) explains that learning based on activities is generally much more effective than being based on presence, material and media. The reason is the activity-based way of learning to get students fully involved. Good learning is to combine physical movements, with thinking (intellectual) activities and the use of all senses of hearing (audio) and sight (visual). The four elements must run synergistically, integrated and simultaneously.

Meier (2003: 81) argues that learning does not automatically increase by telling people to stand and move here and there, but combining physical movement with intellectual activity and using all the senses can have a major effect on learning. Meier added the Intelligence element from the learning proposed by DePorter and the learning was later called SAVI learning (Somatic, Auditory, Visualization, Intellectually) which was later called by adding the Repetition element. This repetition element needs to be added because in learning, repetitions are needed so that the information obtained is not easily lost and learning will be more meaningful. The explanation of the SAVIR learning strategy is as follows:

1. Somatic Learning: Somatic or somatic which means body movements (hand-on, physical activity) where learning by experiencing and doing with the sense of touch, kinesthetic, practical involves physically and uses and moves the body when learning. (Learn to move and do) 
2. Auditory Learning: Auditory which means that learning must be by listening, listening, speaking, presenting, arguing, expressing opinions, and responding. Our hearing is stronger than we realize. Our ears respond to and store auditory information without us even knowing it. (Learn to speak and listen).

3. Visual Learning: Visualization which means that learning must use the eye senses through observing, drawing, demonstrating, reading, using media and teaching aids. Visual learners learn best when they can see real-world examples, diagrams, idea maps, icons, pictures, and descriptions of all kinds of things while they are learning. (Learn by observing and describing).

4. Intellectual Learning: Intellectually which means that learning must use the ability to think (mind-on). Learning must be with the concentration of the mind and practice using it through reasoning, investigating, identifying, discovering, creating, constructing, solving problems, and applying. Is a means by which humans think, reflect, solve problems and construct meaning, connect mental, physical, emotional, and intuitive experiences (learn to solve problems by reflecting).

5. Repetition Learning: Repetition is a repetition which means deepening, expanding, strengthening in the way students are trained through assignments or quizzes. (Learn to solve problems by repeating)

SAVIR learning adheres to the flow of modern cognitive science which states that the best learning involves emotions, the whole body, all senses, and all personal depth and breadth, respecting the learning styles of other individuals by realizing that people learn in different ways ( Sugiarti, 2002: 56). In this lesson, students are required to seek and find solutions to problems by doing. The five components of SAVIR are integrated in such a way that students and teachers can together liven up the classroom atmosphere. Learning is packaged in a varied atmosphere so that it is not boring.

\subsection{Problem Based Learning Model}

Problem-based learning is one of the learning models associated with contextual learning (Sugiarti, 2012, 58). Learning means being faced with a problem, which then through problem solving, through this problem students learn more basic skills.

Before starting the teaching-learning process in the classroom, students are asked to observe a phenomenon first. Then students are asked to note the problems that arise. After that, the teacher's job is to stimulate students to think critically and creatively in solving existing problems. This is in line with Himelo-Silver's opinion (Eggen: 2012) which states that problembased learning is a set of teaching models that use problems as a focus for developing problemsolving skills, materials and self-regulation. In this learning process, the learning process is no longer seen as a process where the teacher provides a lot of information to students through repetition and reinforcement, but the teacher only acts as a facilitator (Solihin, 2011: 45). The teacher's job is to direct students to ask questions, prove assumptions, and listen to opinions that differ from them.

Herman (Solihin, 2011: 46) states that problem-based learning fundamentally changes the view of the teaching and learning process from teaching teachers to learning learners. In this learning, students are required to work actively, cooperatively and be part of the group. Eggen (2012: 111) states that problem-based learning can be applied in classroom learning at two levels, namely first, students must solve a specific problem and understand the material related to it and second, students must develop problem solving skills and become independent learners. 


\subsection{Creative Thinking}

Creativity is a person's ability to create something new, either in the form of ideas o $\mathrm{r}$ works or in combination with existing things, all of which are relatively different from what has been there before. Creative thinking is an exploration activity to generate new ideas that are different from existing ones.

As for the characteristics that characterize the ability to think, according to Guilford (Efendi, 2005: 89) one concept with another. There are five: fluency, flexibility, originality, elaboration and redefinition. Fluency is the ability to generate multiple ideas. Flexibility is the ability to develop a variety of solutions or approaches to problems. Originality is the ability to decide ideas in ways that are original, not clichéd. Elaboration is the ability to describe something in detail. Redefinition is the ability to view a problem from a perspective that is different from what many people already know.

\subsection{Interactive Media}

Multimedia Interactive can be used at various levels of education and various fields of study. The nature of this media is not only interactive but also multimed ia in nature, there are complete media elements including sound, animation, video, text and graphics (Krisnadi, 2013; 34). Learning media are all forms of stimulants and tools provided by the teacher to encourage students / students to learn quickly, precisely, easily, correctly and not to verbalism (Hanafiah, 2008: 45).

Interactive multimedia can guide students / students thoroughly to master the material quickly and interestingly. Another advantage of interactive disks is that students can learn independently, not necessarily depending on the teacher / lecturer. The material taught on the disc can be directly practiced by students. There is a repeat function (repeat) which is useful for repeating material over and over again for overall mastery (Sugiarti: 2012,37)

\subsection{Conventional Learning}

Conventional teaching or traditional teaching is teaching given by teachers / lecturers to all students / students together with events that are commonly used. Making the teacher / lecturer a center, which means that the teacher / lecturer is the main driver of the teaching and learning process (Suryadi, 2009: 55). In this teaching, the teacher usually delivers teaching by lecturing by conveying information orally from a person to a number of listeners in a room (Suryadi, 2009: 52).

Lecturer-centered activity and communication that occurs in only one direction, from speaker to listener. In the lecture method, the teacher plays a major role in determining the content and sequence of steps in conveying the content or material to students. In this teaching, the teacher / lecturer dominates teaching and learning activities, defining the meaning and explanation of formulas which is done by the teacher himself (Suryadi, 2009: 57). Giving examples are given and done by the teacher / lecturer himself. The teacher / lecturer steps are followed carefully by the student / student. They only imitate the work methods and solutions done by the teacher / lecturer.

\section{Methods}

Development research that produces products in the form of learning strategies or research and development methods is a research method used to produce a particular product and test the effectiveness of the product (Sugiyono, 2013: 297). This study aims to develop a 
learning strategy, namely the Application of Problem Based Learning Strategies in an Effort to Improve the Understanding of the Constitutional Court. Multicultural-Based Social Studies Learning in Post-Pendas UMP Students. This research procedure adapts the ADDIE development model which consists of five stages including analysis, design, development, implementation, and evaluation (Sugiyono, 2015: 200). The ADDIE model is chosen because the ADDIE development model is effective, dynamic and supports the performance of the program itself (Warsita, 2011: 7). The ADDIE model consists of 5 components that are interrelated and structured systematically, which means that from the first stage to the fifth stage in its application, it must be systematic and cannot be sorted randomly. These five stages or steps are very simple when compared to other design models. it is simple and systematically structured, so this design model is easy to understand and apply. elopment)

The research procedure used and the development according to the implementation of the SAVIR strategy were carried out in five stages, namely: 1). Analysis Stage (Analysis); 2) Design Phase (Design); 3). Development Stage (Development); 4) Implementation Stage (Implementation); 4). Evaluation Phase (Evaluation).

Place and Time of Research: 1) Place of research in UMP, 2) Time of research was carried out for 4 (four) months during lectures December 2019-July 2020, 3) Research subjects are students of Post basic educational Program study who teach courses Multicultural Based Social Studies Learning.

Data collection techniques, which were collected and developed were 1) interviews, 2) questionnaires, 3) tests, 4) documentation studies. Research instruments, collection and development instruments arranged in this study are: 1). Interview Guidelines, 2). Questionnaire sheet, 3). UAS Problem. Data analysis techniques used in this study are: 1). Quantitative Data Analysis: Analysis of strategy validity, analysis of strategy practicality, analysis of strategy effectiveness; 2). Qualitative Descriptive Data Analysis: Data collection, data reduction, data presentation, conclusion

\section{Results and Discussion}

\subsection{How is the description of SAVIR strategy planning in Multicultural-Based Social Studies learning for Post-Pendas PPS UMP students}

The description of the Multicultural-Based Social Studies Learning course is as follows: 1) Multicultural social studies education can be formulated as a form of awareness of cultural diversity, human rights and the reduction or elimination of various types of prejudice or prejudice to build a just and advanced community life, Education multiculturalism is also defined as a strategy to develop awareness of one's pride in one's nation (The pride in one's ho me nation); 2) Multicultural social studies education must be developed in Indonesia in line with the development of democracy as a buffer for the policy of decentralization and regional autonomy (Otda), which if it is carried out carefully will actually plunge us into national divisions (national disintegration and separatism); 3) To realize the models of multicultural education in Indonesia, it is necessary to consider the combination of existing models, multicultural education can include three types of transformation: (a) self-transformation; (b) school transformation and teaching and learning processes; (c) transformation of society; 4) In principle, multicultural education is education that respects differences, always creates structures and processes in which every culture can carry out expressions, tolerance is an attitude 
of accepting that other people are different from us, education that respects and upholds the realization of cultural equality is a necessity for the world our current national education; 5) Multicultural social studies education, there is cultural equality, alternative means of conflict resolution, so that students are not uprooted from cultural roots, as a basis for developing the national curriculum, towards a multicultural Indonesian society; 6) Multicultural social studies education, a conflict study towards peace studies, such as how to: a) avoid extremism and primordialism; b) a portrait of ethnic conflict in Indonesia; c) Ethnic conflict resolution; d) the historical sins of t he New Order; e) conflict resolution attempts to understand subjective culture; f) regional autonomy: Opportunities and Threats of National Integration; g) Peace Studies to assess Conflict; h) Portrait of East Javanese Ethnic Groups in the Era of Otda; i) Portrait of Ethnic Chinese Discrimination Cases; 7) The concept of material on multiculturalbased social studies learning in general and basic, is still needed in the field at the level of implementation. So, the concept of this learning material is expected to be able to open a veil of understanding about: the theoretical concept of the multicultural-based social studies learning field; understand the emergence and theoretical orientation of the Multicultural-Based Semester Course Plan for Social Studies Teaching; using the theory developed in Multicultural-Based Social Studies Teaching; (8) Able to analyze and review the results of social studies studies based on the development of educational and multicultural theories.

4.2 How to improve the concept of Multicultural-Based Social Studies Learning in PostPendas students through the application of problem-based SAVIR strategies

Problem-based learning occurs in four phases, as follows:

Phase 1: Reviewing and presenting problems Lecturer / Teacher reviews the knowledge needed to solve problems and provide students with problems

- Attract students / students and attract them in the lesson

- Informally assess initial knowledge

- Provides a concrete focus for lessons

Phase 2: Develop Strategies students develop strategies to solve problems and the lecturer/ teacher gives them feedback about the strategy

- Ensure as much as possible that students / learners use the approach to solving problems: problems that exist in Indonesia

Phase 3: Implementing the strategy

Learners apply their strategies while lecturers / teachers carefully monitor their efforts and provide feedback

- Give students / learners experience to solve problems

Phase 4: Discuss and evaluate results

Lecturer / teacher guides discussions about students' efforts and the results they get - Gives students / learners feedback about their efforts

4.3 How to increase the creative thinking skills of Post Pendas students through the application of the problem-based SAVIR strategy?

An understanding of the role of social studies education in multicultural educatio $n$ in Indonesia, that is, it is realized that there are problems with multicultural education in Indonesia. do not understand the broad meaning of Pancasila. In social education, the understanding is given that in the community, always side by side with different backgrounds, it is hoped that they can live in peace. Another aspect sometimes in reality 27 emphasizes unity and integrity 
rather than raising awareness of a diverse society or as a pluralistic society. Multicultural policies from the Government are needed in relation to diversity. Furthermore, the existence of community policies can manage to be useful, promote a better life and can reduce prejudice from differences and reduce conflict. b. The Implementation of Multicultural Education In each count ry, there are different policies in developing multicultural education, this is related to whether or not education is suitable with the problems that exist in the country concerned. Several approaches to integrating a multicultural education teaching material include:

1) The contribution approach, this approach is characterized by historical events such as heroes from various different ethnic groups as well as various historical objects that can be used as learning media in accordance with developments in Indonesia

2) An additive approach, an approach that puts more emphasis on additional material, which is related to the main themes and concepts of a curriculum in relation to the structure, objectives and aspects of the basic characteristics of learning. Can be used as a support such as books, or others that do not change the curriculum material substantially.

3) The transformation approach, this approach changes the basic assumptions of the curriculum so that students can be competent in seeing various problems and issues that occur from various perspectives with different backgrounds.

4) The social action approach, this approach covers a wide variety of elements of the transformation approach, where students are required to develop actions related to the concept, issue or problem being studied. The goal is that students can criticize the social problems of learning fiber learning to decide a related policy, students are expected to get values, knowledge and skills that can be used to participate in social change. So that it is hoped that the forms of groups or groups of race, ethnicity, culture that were previously ignored can participate together in society (Banks, 1993). Direct and indirect expectations of social studies subject learning can teach knowledge and transmission of cultural values, good behavior so that they can have a big contribution to creating character in students and being able to become students who have better moral values. Some examples include respecting differences in religion, cultural and racial differences in society and complying with legal regulations that apply in the State. In class learning activities, for example, you can apply the discussion method so that students are more communicative and active, where they can mutually argue or argue from various different backgrounds so that mutual respect for these differences can be realized. In addition, student activeness can increase curiosity in obtaining the development of information on all sources that can be used as an addition to discussion, however the teacher must explain how to obtain this information to how it can be used for joint discussions.

Another method in social studies learning can apply learning directly to actual situations, such as social problem topics, which can be done by looking for real problems in the environment around the place of learning, then students are trained to be able to make decisions or provide solutions to these problems. Social studies education learning in multicultural education is expected to increase student participation or student contribution in solving various problems that exist around them related to the development of multicultural problems today. Social studies education plays a very important role in multicultural development, closely related to the current era of globalization. Social studies education in it provides learning knowledge about democratic values, culture, political science, history, law, philosophy, anthropology and sociology. Some of his social science presentations include; fellow living beings have the same rights and obligations in the recognition of the Indonesian State, the togetherness of a person who lives together in a particular area of society as well as between 
regions. Furthermore, there is an orientation at the level of social welfare which is a dream for all human beings, and so on which relates to life together. In addition, social studies education is expected to be able to apply knowledge and skills, a positive attitude in accordance with the environmental conditions surrounding the development of science and technology. Multicultural insight is also very much needed in the current era related to developments in the era of globalization, competing in the development of education and technology and to reduce the emergence of discriminatory problems in learning activities in various fields of school to university. Thus, it is hoped that the integration of social studies education learning in multicultural education can contribute to creating a strong society in the midst of various developments in globalization and upholding the basic philosophy of the country, namely "diversity" so that a peaceful, harmonious community life can be realized even though there are differences and social studies education can be the driving force in the development of a more advanced, improved Indonesian education is better characterized by Indonesian culture.

\section{Conclusion}

The research objectives were, 1) The benefits of research, in general, the results of this study are expected to contribute thoughts to multicultural-based social studies learning and can be useful as an alternative to improve students' conceptual understanding and creative thinking skills in multicultural-based social studies lectures / learning through the application of the problem-based SAVIR strategy; 2) Practically the results of this research can be used as, input and consideration for planning and increasing understanding of concepts and the ability to think creatively in Multicultural-Based Social Studies learning also in other subjects, and students through the use and selection of strategies and learning models in lectures; the application of problem-based SAVIR strategies and students' thinking abilities after implementing the problem-based SAVIR strategy in the teaching and learning process; and a contribution of thought through educational research related to learning models, so that learning becomes more interesting, not boring and creates creative thinking; 3) With multicultural-based social studies learning, it is hoped that it can bring better changes from various cultures, ethnicities, ethnicities, different religions, which can instill awareness of students who have useful social values as a form of contribution in overcoming problems in the surrounding community in the future. come. So that the role of social studies for multicultural education can contribute to the improvement of the reality of life, with students / students having an attitude of mutual respect and accepting various differences, having a strong character, having moral values, having sensitivity to social conditions that require, prioritizing values value is not just knowledge.

\section{References}

[1] Akhmad Hidayatullah Al Arifin, 2012. Implementasi pendidikan multikultural dalam praksis pendidikan di Indonesia. Jurnal Pembangunan Pendidikan: Fondasi dan Aplikasi Volume 1, Nomor 1, Juni 201

[2] Banks, James A. 1993. An Introduction to Multicultural Education. Boston: Allyn and Bacon.

[3] Choirul Machfud. 2005. Pendidikan Multikultural. Yogyakarta: Pustaka Pelajar.

[4] Hamdan Mansur. 2004. Pembinaan Kelompok Mata Kuliah Pengem-bangan Kepribadian. Jakarta: Universitas Negeri Jakarta 
[5] Ichas Hamid Al-Lamri dan Tuti Istianti Ichas. 2006. Pengembangan Pendidikan Nilai dalam Pelajaran Pengetahuan Sosial di SD. Jakarta: DEPDIKNAS

[6] Liliweri. Alo. 2005. Prasangka \& Konflik: Komunikasi Lintas Budaya Masyarakat Multikultural. Yogyakarta. LKiS.

[7] Meier, Dave. 2002. The Accelarated Learning Hand Book. Panduan Kreatif danb Efektif Merancang Program Pendidikan dan Penelitian. Bandung: Kaifa.

[8] Ngalimun. 2012. Strategi dan Model Pembelajaran. Banjarmasin: Aswaja Pressindo.

[9] Suyatno. 2007. Aneka Model Pembelajaran Bahasa Indonesia. Surabaya: Unesa.

[10] Shoimin, Aris. 2014. 68 Model Pembelajaran Inovatif dalam Kurikulum 2013. Yogyakarta: ArRuzz Media.

[11] Saidiharjo. 2004. Konsep Dasar Ilmu Pengetahuan Sosial (IPS). Yogyakarta: Progra Pascasarjana UNY.

[12] Sudrajat. Pendidikan Multikultural Untuk Meningkatkan Kualitas Pembelajaran Ips Di Sekolah Dasar. IPSINDO No. 1, Volume 1, Maret 2014.

[13] Udin S. Winataputra, dkk. 2007. Teori Belajar dan Pembelajaran. Jakarta. Universitas Terbuka 